\title{
Aggressiveness of breast cancers found with and without screening
}

\author{
P J Klemi, H Joensuu, S Toikkanen, J Tuominen, O Räsänen, J Tyrkkö, I Parvinen
}

\section{Abstract}

Objective-To examine how breast cancers found by mammographic screening differ from those found outside screening.

Design-Comparative cohort study.

Setting-Turku, southwestern Finland.

Patients -126 women aged $40-74$ years with breast cancer detected during the first round of mammographic screening in $1987-90$ and 125 women within the same age range with breast cancer detected outside screening during the same period.

Main outcome measures-Primary tumour size, axillary nodal status, histological features, oestrogen and progesterone receptor concentrations, ploidy, and $S$ phase fraction.

Results -Compared with the controls women with cancers detected by screening had a smaller primary tumour $(57(46 \%)$ screened $v 11(10 \%)$ controls had tumours $\leqslant 11 \mathrm{~mm}$ in diameter, $\mathrm{p}<0.0001$ ), and less often had axillary nodal metastases (104 (83\%) screened $v 71(57 \%)$ controls node negative,

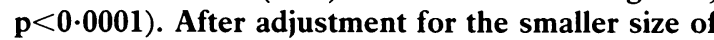
the primary tumour compared with control cancers, those cancers detected by screening were less likely to have axillary nodal metastases (odds ratio 0.44 , $95 \%$ confidence interval 0.23 to 0.84 ), poor histological differentiation $(0.20,0.08$ to 0.49$)$, high mitotic counts $(0.38,0 \cdot 15$ to 0.97$)$, tumour necrosis $(0.45,0.22$ to 0.93$)$ or to be of the ductal histological type $(0.46,0.22$ to 0.95$)$. They had low oestrogen receptor $(0.29,0.12$ to 0.70$)$ and progesterone receptor $(0.35,0.17$ to 0.92$)$ concentrations less often and had smaller $S$ phase fractions $(0.72,0.55$ to 0.96 ) than control cancers.

Conclusions-Even after adjustment for the smaller size of screen detected breast cancers, their histological and cytometric features suggest low malignant potential. They may also be less likely to metastasise to axillary lymph nodes than cancers found outside screening.

\section{Introduction}

Mass screening for breast cancer by mammography has been found to reduce mortality from breast cancer, ${ }^{1.3}$ but the reduction has not been significant in all trials. ${ }^{\text {th }}$ A plausible explanation for the effect of screening on mortality is the smaller size and stage of carcinomas detected by screening. ${ }^{1}$

Necropsy studies suggest that in situ breast carcinoma is common in the general population in young and middle aged women and undiagnosed invasive breast cancer may also occur. Such cancers with a low malignant potential might be detected by mass screening. At present there are, however, few data available on the biological aggressiveness of breast cancer detected by screening compared with that first suspected by the woman herself or by her clinician.

To study the biological aggressiveness of breast carcinoma detected by screening we compared the clinical and histological features, oestrogen and progesterone receptor concentrations, ploidy, and S phase fraction of breast cancers detected by mammography with those of control cancers found without screening at the same time in an urban female population.

\section{Subjects and methods}

A screening programme based on mammography for all women aged from 40 to 74 years was started in Turku, southwestern Finland, in 1987. The female population of the city is about 86000 . During the first round of screening in $1987-90,31927$ women $(87 \cdot 7 \%$ of the 36400 invited) had bilateral mammography with two projections. The mammograms were reviewed independently by two radiologists. Cancers detected among the screened women between screening rounds (interval cancers) or cancers detected in screening after the first round of screening were not included in the study. The control cases consisted of women aged between 40 and 79 who lived in the city, and who had breast cancer diagnosed in 1987-90 before they received an invitation to screening mammography. The control cases were found by searching the files of the local hospitals and the Finnish cancer registry.

We reviewed the hospital records and staged cancers according to the postsurgical Union of International Cancer Classification TNM classification. ${ }^{8}$ Primary tumour size (available in 238 cases) was determined from the surgical and histopathological reports. The dextran coated charcoal method was used for oestrogen and progesterone receptor assays, and these assays were done for 173 screened women and 165 control women with invasive cancer. The cut off value for oestrogen receptor positivity was $10 \mathrm{fmol} / \mathrm{mg}$ protein and for progesterone receptor positivity $30 \mathrm{fmol} / \mathrm{mg}$ protein.

The histological samples of both groups were assessed according to similar principles. Analyses of the nuclear DNA content and hormone receptor contents were carried out blindly without knowledge of whether cancer was detected in screening or outside it.

The histological type and grade of the cancers were determined according to the World Health Organisation classification" with slight modifications. One pathologist (ST) assessed all tumours, and they were classified into four types ${ }^{11}$ : firstly, infiltrating ductal carcinoma not otherwise specified (including apocrine, mixed mucinous, and atypical medullary types); secondly, infiltrating lobular carcinoma with variants; thirdly, other special types (including tubular, medullary, adenoid cystic, papillary, metaplastic, and pure mucinous carcinomas); and, fourthly, carcinoma in situ. The number of mitoses counted was the number per high power field, taking the average value from 10 fields (Leitz Orthoplan, $40 \times$ plan objective), and nuclear pleomorphism was defined as degree of irregularity in size, shape, and staining. Tumour 
necrosis was graded as none, spotty, moderate, or severe, but intraductal comedo necrosis was not included in its assessment. Other histopathological features were semiquantitatively evaluated if they could be assessed with confidence.

Nuclear DNA content was analysed from paraffin embedded tissue by flow cytometry. " DNA was stained with propidium iodide, and flow cytometry was done with a FACScan flow cytometer (Becton-Dickinson Immunocytometry Systems, Mountain View, California). For each DNA histogram 20000 particles were analysed. DNA giving histograms with a symmetrical G0/Gl peak was classified as diploid, and that giving other patterns as non-diploid. The mean coefficient of variation of diploid peaks was $5 \cdot 7 \%$ (SD $1 \cdot 5 \%$, range $2 \cdot 7-8 \cdot 5 \%$ ). Ploidy was not determined in 26 cases of invasive cancer because of lack of tissue, poor quality of DNA histogram, or uncertainty about classification of the histogram. S phase fraction was analysed in 168 cases by the rectangular method ${ }^{12}$; the

TABLE I-Comparison of size related parameters in invasive breast carcinomas detected with and without screening

\begin{tabular}{|c|c|c|c|}
\hline Variable & $\begin{array}{l}\text { No }(\%) \text { detected } \\
\text { by screening } \\
(n=126)\end{array}$ & $\begin{array}{l}\text { No }(\%) \text { of } \\
\text { controls } \\
(n=125)\end{array}$ & $\mathrm{p}$ Value \\
\hline $\begin{array}{l}\text { Primary tumour size }(\mathrm{mm}) \text { : } \\
3-10 \\
11-20 \\
21-30 \\
>30\end{array}$ & $\begin{array}{l}57(46) \\
39(31) \\
21(17) \\
8(6)\end{array}$ & $\left.\begin{array}{l}11(10) \\
44(40) \\
31(28) \\
25(23)\end{array}\right\}$ & $<0.0001$ \\
\hline $\begin{array}{l}\text { Axillary nodal status: } \\
\text { Negative } \\
\text { Positive }\end{array}$ & $\begin{array}{r}104(83) \\
22(18)\end{array}$ & $\left.\begin{array}{l}71(57) \\
53(43)\end{array}\right\}$ & $<0.0001$ \\
\hline $\begin{array}{l}\text { Postsurgical stage: } \\
\text { I } \\
\text { II } \\
\text { III } \\
\text { IV }\end{array}$ & $\begin{array}{l}85(68) \\
37(29) \\
2(2) \\
1(1)\end{array}$ & $\left.\begin{array}{r}33(30) \\
57(50) \\
7(6) \\
16(14)\end{array}\right\}$ & $<0.0001$ \\
\hline
\end{tabular}

TABLE II-Comparison of histological parameters, ploidy, and $S$ phase fraction in invasive breast cancers detected with and without screening

\begin{tabular}{|c|c|c|c|c|}
\hline Variable & $\begin{array}{c}\text { No }(\%) \\
\text { detected by } \\
\text { screening } \\
(\mathrm{n}=126)\end{array}$ & $\begin{array}{l}\text { No }(\%) \\
\text { controls } \\
(\mathrm{n}=125)\end{array}$ & $\begin{array}{l}\text { Unadjusted odds } \\
\text { ratio } \\
\text { (95\% confidence } \\
\text { interval) }\end{array}$ & $\begin{array}{l}\text { Adjusted odds } \\
\text { ratio } \\
\text { (95\% confidence } \\
\text { interval) }\end{array}$ \\
\hline $\begin{array}{l}\text { Histological differentiation: } \\
\text { Poor } \\
\text { Moderate } \\
\text { Good }\end{array}$ & $\begin{array}{l}16(13) \\
62(49) \\
48(38)\end{array}$ & $\begin{array}{l}39(33) \\
64(54) \\
16(13)\end{array}$ & $\begin{array}{l}0.14(0.06 \text { to } 0.31)^{\star} \\
0.32(0.17 \text { to } 0.63) \dagger\end{array}$ & $\begin{array}{l}0.20(0.08 \text { to } 0.49)^{\star} \\
0.35(0.21 \text { to } 0.57)\end{array}$ \\
\hline $\begin{array}{l}\text { Tumour necrosis: } \\
\text { Spotty, moderate, or severe } \\
\text { None }\end{array}$ & $\begin{array}{r}16(13) \\
104(87)\end{array}$ & $\begin{array}{l}39(35) \\
74(65)\end{array}$ & $0.29(0.15$ to 0.56$)$ & $0.45(0.22$ to 0.93$)$ \\
\hline $\begin{array}{l}\text { Mitotic counts/high power field: } \\
>3 \\
2 \text { to } 3 \\
\text { Rare }\end{array}$ & $\begin{array}{l}9(8) \\
41(34) \\
70(58)\end{array}$ & $\begin{array}{l}26(23) \\
45(40) \\
42(37)\end{array}$ & $\begin{array}{l}0.22(0.10 \text { to } 0.52) \ddagger \\
0.59(0.33 \text { to } 1.03) \S\end{array}$ & $\begin{array}{l}0.38(0.15 \text { to } 0.97) \ddagger \\
0.63(0.34 \text { to } 1.19) \S\end{array}$ \\
\hline $\begin{array}{l}\text { Oestrogen receptor: } \\
<10 \mathrm{fmol} / \mathrm{mg} \text { protein } \\
>10 \mathrm{fmol} / \mathrm{mg} \text { protein }\end{array}$ & $\begin{array}{r}9(12) \\
66(88)\end{array}$ & $\begin{array}{l}28(29) \\
70(71)\end{array}$ & $0.34(0.15$ to 0.78$)$ & $0 \cdot 29(0 \cdot 12$ to $0 \cdot 70)$ \\
\hline $\begin{array}{l}\text { Progesterone receptor: } \\
<30 \mathrm{fmol} / \mathrm{mg} \text { protein } \\
>30 \mathrm{fmol} / \mathrm{mg} \text { protein }\end{array}$ & $\begin{array}{l}23(32) \\
48(68)\end{array}$ & $\begin{array}{l}49(52) \\
45(48)\end{array}$ & $0.44(0.23$ to 0.83$)$ & $0.35(0.17$ to 0.92$)$ \\
\hline $\begin{array}{l}\text { Histologic type: } \\
\text { Ductal } \\
\text { Other }\end{array}$ & $\begin{array}{l}93(74) \\
33(26)\end{array}$ & $\begin{array}{r}107(86) \\
18(14)\end{array}$ & $0.47(0.25$ to 0.90$)$ & $0.46(0.22$ to 0.95$)$ \\
\hline $\begin{array}{l}\text { Type of tumour margin: } \\
\text { Definite or questionable } \\
\text { None }\end{array}$ & $\begin{array}{l}48(40) \\
71(60)\end{array}$ & $\begin{array}{l}51(46) \\
61(54)\end{array}$ & $0.81(0.48$ to 1.36$)$ & $0.73(0.41$ to 1.31$)$ \\
\hline $\begin{array}{l}\text { Invasion to lymphatic vessels: } \\
\text { Present } \\
\text { Absent }\end{array}$ & $\begin{array}{l}42(35) \\
79(65)\end{array}$ & $\begin{array}{l}36(32) \\
75(68)\end{array}$ & $1.11(0.64$ to 1.91$)$ & $1.54(0.83$ to 2.87$)$ \\
\hline $\begin{array}{l}\text { Ploidy: } \\
\text { Diploid } \\
\text { Non-diploid }\end{array}$ & $\begin{array}{l}52(44) \\
65(56)\end{array}$ & $\begin{array}{l}34(32) \\
74(69)\end{array}$ & $1.74(1.01$ to 3.00$)$ & $1.43(0.94$ to 2.62$)$ \\
\hline $\begin{array}{l}\text { S phase fraction: } \\
\text { No of cancers } \\
\text { Mean (SD) value (\%) } \\
\text { Median } \\
\text { Range } \\
\text { Unadjusted geometric mean } \\
\text { Adjusted geometric mean }\end{array}$ & $\begin{array}{l}84 \\
5 \cdot 9(4 \cdot 5) \\
4 \cdot 6 \\
2 \cdot 0-28 \cdot 0 \\
4 \cdot 82\end{array}$ & $\begin{array}{l}84 \\
9 \cdot 8(7 \cdot 0) \\
7 \cdot 9 \\
1 \cdot 7-28 \cdot 3 \\
7 \cdot 56\end{array}$ & $0.64(0.52$ to 0.79$)$ & $0.72(0.55$ to 0.96$)$ \\
\hline
\end{tabular}

$\star$ Odds ratio for poor $v$ good differentiation. †Odds ratio for moderate $v$ good differentiation. fraction could not be analysed in 57 cases because of the presence of a small aneuploid stemline, overlapping stemlines, or nuclear debris. Ploidy and $S$ phase fraction parameters were determined blind and all other tests were done blind to results of ploidy and $S$ phase fraction tests.

\section{STATISTICAL METHODS}

The two way frequency tables were analysed with the $\chi^{2}$ test. The $\chi^{2}$ test of linear trend was used for ordinal variables. Comparison of $S$ phase fractions between the two groups after adjusting for primary tumour size was done by two way analysis of variance after logarithmic transformation. Interactions between control cancers and those detected by screening and the various histological parameters after adjusting for primary tumour size were analysed with a log linear model. Adjusted and unadjusted odds ratios with their $95 \%$ confidence intervals were calculated. ${ }^{13}$ Statistical analyses were done with the biomedical programs data package (BMDP Statistical Software, Department of Biomathematics, University of California, Los Angeles).

\section{Results}

Forty six per cent of the women with invasive cancers detected by screening had a primary tumour less than $11 \mathrm{~mm}$ in diameter compared with only $10 \%$ of the controls, and fewer screened women had axillary nodal metastases than controls $(p<0.0001$ for both, table I). Compared with the control cancers carcinomas detected by screening were less likely to be poorly differentiated (odds ratio $0 \cdot 14,95 \%$ confidence interval 0.06 to 0.31 , have tumour necrosis $(0.29,0.15$ to 0.56$)$, have a high mitotic count $(0.22,0 \cdot 10$ to 0.52$)$, or be of the ductal type $(0.47,0.25$ to 0.90$)$ (table II). Screen detected cancers were also less likely to have low oestrogen receptor $(0.34,0 \cdot 15$ to 0.78$)$ or progesterone receptor $(0.44,0.23$ to 0.83$)$ concentration and were more likely to be DNA diploid $(1.74,1.01$ to 3.00) and have smaller $S$ phase fractions $(0.64,0.52$ to $0 \cdot 79)$ than the controls.

After adjustment for the size of the primary tumour (tumour diameter $<10 \mathrm{~mm} v 11-20 \mathrm{~mm}, v 21-30 \mathrm{~mm}$, and $>30 \mathrm{~mm}$ ) in a multivariate $\log$ linear model most of the differences between cancers detected by screening and control cancers remained significant (table II). Cancers detected by screening also had fewer axillary nodal metastases $(0.44,0.23$ to 0.84$)$ after adjustment for tumour size. However, there was no difference between the groups in the type of tumour margin circumscription, lymphatic vessel invasion, or DNA ploidy after adjusting for size.

\section{Discussion}

The purpose of mammographic screening is to detect cancers early in their clinical course before they have had time to give rise to clfnical symptoms and to metastasise. In line with earlier studies ${ }^{136}$ we found that cancers detected by screening were smaller and had fewer axillary nodal metastases than the control cases. However, screen detected cancers were also associated with features suggesting low level of biological aggressiveness, such as high histological grade of differentiation, low mitotic counts, little tumour necrosis, and low $\mathrm{S}$ phase fractions. It is therefore possible that some of the cancers detected by screening might not surface during the lifetime of the woman and never threaten her life.

When cancers grow larger they may become less differentiated because of malignant progression. ${ }^{14}$ Thus if cancers detected by screening are compared with self detected cancers without adjustment for 
tumour size, larger cancers are compared with smaller ones and screen detected cancers may appear less aggressive simply because of their shorter biological age. However, our results indicate that screen detected breast carcinomas are significantly associated with several features associated with low malignant potential even after adjustment for their smaller size.

Our finding of low malignant potential in screen detected breast cancer is supported by two smaller studies. In one study 37 breast cancers detected by mammography were found to have smaller $S$ phase fractions and less DNA aneuploidy than 60 control cancers diagnosed a few years earlier, but no adjustment for size of the cancers was made. ${ }^{15}$ Similarly, in another study 42 breast cancers found in a palpation based screening were found to have less aggressive histological and cytometric features than in clinical controls. ${ }^{16}$

The lower malignant potential of screen detected breast cancer may decrease the efficiency of screening in saving lives and may at least partially explain why significant reductions in mortality have not always been achieved by screening. ${ }^{4-6}$ If treatment of breast cancer is based only on the size of the primary tumour many women with cancer detected by screening may be overtreated.

This study was supported by the Finnish Foundation for Cancer Research.

I Shapiro S, Venet W, Strax P, Venet L, Roeser R. Selection, follow-up, and analysis in the health insurance plan study: A randomized trial with breast cancer screening. National Cancer Institute Monographs 1985;67:65-74
2 Verbeek ALM, Holland R, Sturmans F, Hendriks JHCL, Mravunac M, Day NE. Reduction of breast cancer mortality through mass screening with modern mammography. First results of the Nijmegen project, 1975-1981. Lancet 1984;ii:1222-4.

3 Tabar L, Fagerberg CJG, Gad A, Baldetorp L, Holmberg LH, Gröntoft O. Reduction in mortality from breast cancer after mass screening with mammography. Lancet 1985; ;:829-32.

4 Andersson I, Aspergren K, Janzon L, Landberg T, Lindholm K, Linell F Mammographic screening and mortality from breast cancer: the Malmö mammographic screening trial. $B M \mathcal{J}$ 1988;297:943-8.

5 Chamberlain J, Coleman D, Ellman R, Moss SM. First results on mortality reduction in the UK trial of early detection of breast cancer. Lancet 1988;ii:411-6.

6 Roberts MM, Aleksander FE, Anderson TJ, Chetty U, Donnan PT, Forrest $P$. Edinburgh trial of screening for breast cancer: mortality at seven years. Lancet 1990;335:241-6.

7 Nielsen M, Thomsen JL, Primdahl S, Dyreborg U, Andersson JA. Breast cancer and atypia among young and middle-aged women: a study of 110 medicolegal autopsies. Brf Cancer 1987;56:814-9.

8 Union of International Cancer Classification. TNM classification of malignan tumours. 4th ed. Geneva: UICC, 1987.

9 World Health Organisation. Histological typing of breast tumours. International classification of tumours No 2. 2nd ed Geneva: WHO, 1981.

10 Toikkanen $S$, Jeensur $H$. Prognotic factors and long-term survival in breast oikkanen S, Joensuu H. Prognostic factors and long-term surviva

11 Hedley DW, Frined urban population. AP, RIS I for analysis of cellular DNA content of paraffin-embedded pathological material using flow cytometry. I Histochem Cytochem 1983;31:1333-5.

12 Camplejohn RS, Macartney JC, Morris RW. Measurement of S-phase Camplejohn RS, Macartney JC, Morris RW. Measurement of S-phase
fractions in lymphoid tissue comparing fresh versus paraffin-embedded tissue and $4^{\prime}, 6^{\prime}$-diamino-2 phenylindole dihydrochloride versus propidium iodide staining. Cytometry 1989;10:410-6.

3 Agresti A. Categorical data analysis. New York: Wiley, 1990.

14 Koscielny S, Tubiana M, Le MG, Valleron AJ, Mouriesse H, Contesso G, et al. Breast cancer: relationship between the size of the primary tumour and probability of metastatic dissemination. Br f Cancer 1984;49:709-15.

15 Kallioniemi OP, Kärkkäinen A, Auvinen O, Mattila J, Koivula T, Hakama M. DNA flow cytiometric analysis indicates that many breast cancers detected in the first round of mammographic screening have a low malignan potential. Int $\mathcal{A}$ Cancer 1988:42:697-702.

16 Joensuu H, Toikkanen S, Klemi PJ. Histological features, DNA content and prognosis of breast carcinoma found incidentally or in screening. Br f Cancer 1991;64:588-92.

(Accepted 27 November 1991 )

\title{
Community surveillance of complications after hernia surgery
}

\author{
Ian S Bailey, Susan E Karran, Kim Toyn, Patricia Brough, Charles Ranaboldo, Stephen J Karran
}

\section{Abstract}

Objective-To assess the effect of a programme of postoperative community surveillance on the rate of detection of wound complications after operation for inguinal hernia.

Design-Prospective audit of wound complications including complications recorded in case notes and those discovered by community surveillance.

Setting-Academic surgical unit of three consultant surgeons.

Patients -510 patients undergoing elective inguinal hernia repair between June 1985 and August 1989.

Results - The wound infection rate recorded in the hospital notes was $3 \%$ compared with $9 \%$ when additional information was obtained from community surveillance. Wound complications were detected in $143(28 \%)$ patients by community surveillance compared with a complication rate of $7 \%$ in the case records for the same patients.

Conclusions - Wound complications are common after clean surgery in patients discharged home early. Complication rates are a reflection not only of the standards of surgical practice but also the rigour with which they are sought. Before national comparative audit data are published the method of collection must be standardised. For short stay surgery this should include meaningful community surveillance.

\section{Introduction}

All surgeons should now be auditing their practice, as dictated by the government and supported by the royal colleges.' The audit process is still evolving and although many publications have suggested various audit methods, no clear consensus has emerged.

Outcome measurements, apart from death, are often difficult to define in a simple, objective manner. Studies assessing treatment in patients who died in the perioperative period, ${ }^{2}$ or after trauma ${ }^{3}$ have identified important problems of quality of care. These studies, however, encompass only a small percentage of surgical patients.

At a local level audit usually comprises crude case load analysis with some assessment of mortality and morbidity. This may be based on data recorded by junior medical staff in an audit book or on structured audit databases developed recently. Such a process may provide adequate performance assessment for many surgical procedures, but assessment is usually less than adequate for the large and increasing number of short stay and day case procedures. Many patients after such surgery are not followed up at all or are seen some four to six weeks later with a "quick chat" and a cursory examination. Problems mentioned postoperatively have usually resolved by the time of the follow up appointment, and the patient is subsequently discharged with no record being made of such events. The development of purchaser-provider arrangements will, however, increasingly dictate that even this quality check may not happen.

It has many times been suggested that wound infection rates after "clean" surgery provide a good indicator of surgical performance, ${ }^{4}$ and more recently it has been suggested that wound infection rates should be published to identify "good" units. The reported incidence of wound infections, however, may well be as much a reflection of the rigour with which patients 